\title{
Clustering Pada Pelanggan Perusahaan Air Bersih Dengan Algoritma K-Means
}

\author{
Arif Ramadhan Siregar ${ }^{1}$, Sundari Retno Andani ${ }^{2}$, Widodo Saputra ${ }^{3}$ \\ ${ }^{1}$ Mahasiswa Program Studi Sistem Informasi STIKOM Tunas Bangsa, Pematangsiantar \\ ${ }^{2,3}$ AMIK Tunas Bangsa, Pematangsiantar, Indonesia \\ ${ }^{1}$ Siregararif8008@gmail.com
}

\begin{abstract}
progress, and increasing living standards have caused the need for clean Clean water services are a very important component of public services. Water is a basic need that cannot be separated from human life. The supply of clean water is of particular concern to every country in the world, including in Indonesia. Population growth, development water to continue to increase. Technological improvements and rapid population growth are now encouraging mineral water companies to continue to innovate and expand their market network in order to continue to survive and compete with companies - companies. A product that can be desired by consumers must be able to provide satisfaction to consumers who consume these products. In realizing the goals to achieve customer satisfaction, companies must be able to learn in advance about products that consumers are interested in, habits carried out by consumers, why consumers are interested in consuming these items, and how many products are needed by consumers. The author wants clean water customers which will be clustered using the K-means algorithm to do which provinces will get customers of clean water companies.
\end{abstract}

Keywords: PDAM, Data Mining, Clustering, K-Means

\begin{abstract}
Abstrak
Pelayanan air bersih merupakan komponen pelayanan publik yang sangat penting. Air merupakan kebutuhan dasar yang tidak dapat dilepaskan dari kehidupan manusia. Penyediaan air bersih menjadi perhatian khusus setiap negara di dunia tidak terkecuali di Indonesia. Pertumbuhan penduduk, perkembangan pembangunan, dan meningkatnya standar kehidupan menyebabkan kebutuhan akan air bersih terus meningkat. Peningkatan teknologi dan pertumbuhan penduduk yang pesat sekarang ini mendorong perusahaan air mineral untuk semakin terus berinovasi dan memperluas jaringan pasarnya agar dapat terus bertahan dan bersaing dengan perusahaan - perusahaan. Suatu produk agar dapat diminati oleh konsumen harus mampu memberikan kepuasan tersendiri kepada konsumen yang mengkonsumsi produk tersebut. Dalam mewujudkan tujuan untuk mencapai kepuasan konsumen tersebut, perusahaan harus mampu untuk mempelajari terlebih dahulu tentang produk yang diminati konsumen, kebiasaan-kebiasan yang dilakukan oleh para konsumen, mengapa konsumen tertarik untuk mengkonsumsi barang tersebut, serta berapa banyak jumlah produk yang dibutuhkan oleh konsumen Dan disini penulis menginginkan pelanggan air bersih yang mana nantinya akan di clustering dengan algoritma K-means untuk melakukan provinsi manakah yang akan mendapatkan pelanggan perusahaan air bersih.
\end{abstract}

Kata Kunci: PDAM, Data Mining, Clustering, K-Means

\section{Pendahuluan}

Air merupakan kebutuhan dasar yang tidak dapat dilepaskan dari kehidupan manusia. Penyediaan air bersih menjadi perhatian khusus setiap negara di dunia tidak terkecuali di Indonesia. Pertumbuhan penduduk, perkembangan pembangunan, dan meningkatnya standar kehidupan menyebabkan kebutuhan akan air bersih terus 
meningkat. Hal ini menjadikan kualitas layanan perusahaan penyedia dan pengelola air bersih sangat dibutuhkan oleh masyarakat Perusahaan Daerah Air Minum (PDAM) mengemban tugas pokok melaksanakan pengelolaan dan pelayanan air bersih untuk meningkatkan kesejahteraan masyarakat sesuai dengan UndangUndang No. 32 tahun 2004, tentang Pemerintahan Daerah.

Berdasarkan survei sosial Ekonomi Nasional (susenas) oleh Badan Pusat Statistik (BPS) terdapat peningkatan rumah tangga yang memiliki akses terhadap sumber air minum di indonesia. Pada 2004, terdapat 8.786 desa atau sekitar 10,8 persen mengalami pencemaran air dari total yaitu 81.626 desa di tanah air. Jawa barat merupakan provinsi dengan jumlah desa yang mengalami pencemaran air paling banyak dibandingkan 33 provinsi lainya. Lebih dari seribu atau sekitar 19 persen desa di jawa barat air di pedesaan tercemar. Provinsi lainya seperti Jawa Tengah, Jawa Timur,Kalimatan Barat, Kalimatan Tengah memiliki jumlah yang mengalami pencemaran air di atas 500. Dan disini penulis menginginkan pelanggan air bersih yang mana nantinya akan di clustering dengan algoritma K-means untuk melakukan provinsi manakah yang akan mendapatkan pelanggan perusahaan air bersih.

Data Mining adalah proses seleksi, eksplorasi, dan pemodelan dari sejumlah data yang besar untuk menemukan pola atau kecenderungan yang biasanya tidak disadari keberadaannya dan dapat dikatakan sebagai proses mengekstrak dari jumlah data besar yang tersedia" [1][2]. Adapun tahapan data mining salah satunya yaitu Clustereng Untuk menghilangkan data noise (data yang tidak relevan/berhubungan langsung dengan tujuan akhir proses datamining, misal: data mining yang bertujuan untuk menganalisa hasil penjualan, maka data-data dalam kumpulan seperti "nama pegawai, umur", dan sebagainya dapat diignore) dan tidak konsisten[3]. Penelitian sebelumnya menjelaskan tentang Penerapan Algoritma K Means Clustering Untuk Pengelompokkan Penyebaran Diare Di Kabupaten Langkat [4] yang mana Hasil dari pengelompokkan daerah penyebaran diperoleh Kecamatan Batang Serangan, Brandan Barat dan Permata Jaya sebagai pusat penyebaran diare pada Cluster pertama dan Kecamatan Hinai dan Sei Bingai menjadi pusat cluster kedua. Berdasarkan penjelasan diatas Diharapkan dengan adanya analisis ini dapat menjadi masukan bagi pemerintah, khususnya bagi provinsi yang menjadi cluster tinggi, rendah, sedang dalam penggunaan air bersih dan untuk mengetahui perkembangan tingkat provinsi yang ada di Indonesia.

\section{Metodologi Penelitian}

$K$-Means merupakan suatu algoritma yang digunakan dalam pengelompokkan secara pertisi yang memisahkan data ke dalam kelompok yang berbeda-berda. Algoritma ini mampu meminimalkan jarak antara data ke clusternya" [5][6]. Secara umum algoritma $K$-Means memiliki langkah-langkah dalam pengelompokan [7]:

1. Inisilisasi: menentukan nilai $K$ centroid yang diinginkan dan metrik ketidakmiripan (jarak) yang diinginkan.

2. Memilih $K$ data dari set $X$ sebagai centroid. Untuk menentukan centroid dapat menggunakan persamaan (1).

$\frac{\text { Jumlah Data }}{\text { Jumlah Class+1 }}$

Mengalokasikan semua data ke centroid terdekat dengan matrik jarak yang telah ditetapkan.

3. Menghitung kembali centroid $C$ berdasarkan data yang mengikuti cluster masing - masing.

4. Mengulangi langkah 3 dan 4 hingga kondisi konvergen tercapai. Berikut ini adalah rumus untuk menentukan jumlah cluster :

$\mathbf{K}=\sqrt{\frac{N}{2}}$ 
Keterangan:

$\mathrm{K}=$ klaster

$\mathrm{N}=$ jumlah data

Menghitung jarak pada ruang jarak Euclidean menggunakan formula:

$D\left(x_{2}, x_{1}\right)=\left\|x_{2}-x_{1}\right\|_{2}=$

$\sqrt{\sum_{j=1}^{p}\left|x_{2 j}-x_{1 j}\right|^{2}}$

Keterangan:

$D=$ euclidean distance

$x$ = banyaknya objek

$\Sigma \mathrm{p}=$ jumlah data record

\section{Hasil dan Pembahasan}

Sumber data penelitian diperoleh dari Badan Pusat Statistik an situs https://www.bps.go.id. Data yang digunakan dalam penelitian ini_persentase laju inflasi berdasarkan kota dari tahun 2010- 2015 yang terdiri dari 33 provinsi. Data hasil akhir yang nantinya akan diolah melakukan clustering dari berdasarkan provinsi yang dicantumkan dalam 3 cluster yaitu cluster tertinggi, cluster sedang dan cluster terendah. Dalam melakukan penelitian ini, penulis melakukan analisa data statistik bersifat sekunder yang dimana data diperoleh tidak dari sumbernya langsung, melainkan sudah dikumpulkan dan diolah secara terinci yang dimana data berkaitan dengan permasalahan yang sedang diteliti dapat dilihat pada tabel 1 .

Tabel 1. Jumlah Pelangan Air Bersih

\begin{tabular}{|c|c|c|c|c|c|c|}
\hline \multirow[t]{2}{*}{ Provinsi } & \multicolumn{6}{|c|}{ Jumlah pelanggan air bersih } \\
\hline & 2010 & 2011 & 2012 & 2013 & 2014 & 2015 \\
\hline Aceh & 111.995 & 131.076 & 137.765 & 146.332 & 148.158 & 163.812 \\
\hline Sumatera Utara & 642.851 & 685.320 & 780.765 & 812.774 & 891.429 & 839.212 \\
\hline Sumatera Barat & 206.787 & 220.873 & 229.561 & 237.718 & 256.152 & 274.384 \\
\hline Riau & 58.865 & 64.610 & 64.108 & 66.002 & 73.085 & 80.824 \\
\hline Jambi & 112.148 & 115.550 & 132.799 & 113.711 & 122.102 & 607.029 \\
\hline Sumatera Selatan & 210.607 & 299.487 & 338.831 & 379.681 & 447.446 & 693.138 \\
\hline Bengkulu & 52.968 & 55.184 & 59.339 & 56.610 & 62.693 & 74.956 \\
\hline Lampung & 66.060 & 79.554 & 88.511 & 67.538 & 75.649 & 79.477 \\
\hline Kep. Bangka Belitung & 15.975 & 16.863 & 20.808 & 18.110 & 19.077 & 21.817 \\
\hline Kep. Riau & 176.196 & 241.429 & 242.602 & 243.715 & 267.300 & 317.639 \\
\hline Dki Jakarta & 1.201 .557 & 1.611 .446 & 805.160 & 809.522 & 820.251 & 837.776 \\
\hline Jawa Barat & 1.386 .562 & 1.140 .474 & 1.189 .249 & 1.411 .853 & 1.364 .622 & 1.278 .987 \\
\hline Jawa Tengah & 1.075 .901 & 1.133 .719 & 1.200 .072 & 1.275 .162 & 1.361 .421 & 1.448 .984 \\
\hline Di Yogyakarta & 118.292 & 122.124 & 129.659 & 133.121 & 140.796 & 147.645 \\
\hline Jawa Timur & 1.529 .809 & 1.355 .320 & 1.432 .272 & 1.557 .030 & 1.629 .663 & 1.176 .421 \\
\hline Banten & 215.275 & 200.111 & 203.897 & 251.301 & 238.103 & 246.957 \\
\hline Bali & 334.055 & 342.412 & 353.747 & 372.463 & 390.306 & 406.959 \\
\hline Nusa Tenggara Barat & 143.465 & 156.685 & 171.677 & 187.959 & 202.145 & 232.662 \\
\hline Kalimantan Barat & 141.103 & 160.914 & 161.810 & 158.431 & 221.150 & 187.904 \\
\hline Kalimantan Tengah & 99.342 & 98.498 & 103.364 & 110.826 & 111.891 & 118.544 \\
\hline Kalimantan Selatan & 373.207 & 398.026 & 429.275 & 324.588 & 360.097 & 370.094 \\
\hline Kalimantan Timur & 304.485 & 321.208 & 457.000 & 329.692 & 370.507 & 379.732 \\
\hline Kalimantan Utara & - & - & - & 26.788 & 36.874 & 41.677 \\
\hline Sulawesi Utara & 168.264 & 180.529 & 250.838 & 268.820 & 120.762 & 134.575 \\
\hline Sulawesi Tengah & 99.195 & 73.505 & 97.203 & 90.205 & 86.407 & 103.847 \\
\hline Sulawesi Selatan & 309.910 & 320.746 & 342.068 & 361.753 & 409.438 & 404.430 \\
\hline Sulawesi Tenggara & 59.275 & 62.609 & 69.480 & 66.344 & 72.625 & 74.327 \\
\hline Gorontalo & 35.620 & 47.114 & 51.738 & 49.593 & 56.141 & 63.098 \\
\hline Sulawesi Barat & 96.502 & 97.925 & 28.894 & 27.043 & 29.366 & 34.767 \\
\hline Maluku & 29.609 & 32.583 & 33.888 & 41.695 & 42.465 & 45.521 \\
\hline Maluku Utara & 33.435 & 35.505 & 37.912 & 58.721 & 51.699 & 62.244 \\
\hline Papua Barat & 15.332 & 17.768 & 19.098 & 19.186 & 18.487 & 22.198 \\
\hline Papua & 42.547 & 42.477 & 44.675 & 44.591 & 46.633 & 46.946 \\
\hline
\end{tabular}


Untuk mendapatkan hasil dari penelitian yang dilakukan, berikut uraian perhitungan manual proses clustereng pelanggan air bersih menggunakan algoritma $K$-Means. Proses clustering dilakukan mulai dari penentuan data yang ingin di cluster. Dalam hal ini variabel data yang ingin di cluster adalah data dari tahun 2010 sampai 2015 dan disini peneliti mengambil nilai rata rata dari tahun 2010 sampai 2015 sebagai data yang akan di cluster. Berikut adalah langkah-langkah penyelesaian yang dilakukan penulis dalam mengelompokkan Rumah Tangga Menguasai Komputer menggunakan algoritma K-Means :

1. Menentukan jumlah data yang akan di cluster, dimana sampel data jumlah pelanggan air bersih yang akan digunakan dalam proses clustereng adalah data jumlah persentase yang terdapat pada Badan Pusat Statistik pada tahun 20102015 dengan jumlah data sebanyak 34 Provinsi. Berikut adalah cara beberapa cara untuk mencari nilai rata-rata

$R 1=111995 / 131076 / 137765 / 146332 / 148158 / 163.812 / 6=139.856$

R2 $=642851 / 685320 / 780765 / 812774 / 891429 / 839212 / 6=775.392$

Sampai R34, dan berikut adalah hasil nilai rata- rata untuk cluster pertama Iterasi 1:

Tabel 2. Penggunaan Air Bersih

\begin{tabular}{clcccc}
\hline No & Provinsi & Nilai Rata-Rata & C1 & C2 & C3 \\
\hline 1 & Aceh & 139.856 & 1306897 & 162013 & 121178 \\
2 & Sumut & 775.392 & 671361 & 473523 & 756714 \\
3 & Sumbar & 237.579 & 1209174 & 64290 & 218901 \\
4 & Riau & 67.916 & 1378837 & 233953 & 49238 \\
5 & Jambi & 200.557 & 1246196 & 101312 & 181879 \\
6 & Sumsel & 394.865 & 1051888 & 92996 & 376187 \\
7 & Bengkulu & 60.292 & 1386461 & 241577 & 41614 \\
8 & Lampung & 76.132 & 1370621 & 225737 & 57454 \\
9 & Kep.Babel & 18.775 & 1427978 & 283094 & 97 \\
10 & Kep. Riau & 248.147 & 1198606 & 53722 & 229469 \\
11 & Dki & 1.014 .285 & 432468 & 712416 & 995607 \\
12 & Jabar & 1.295 .291 & 151462 & 993422 & 1276613 \\
13 & Jateng & 1.249 .210 & 197543 & 947341 & 1230532 \\
14 & Diy & 131.940 & 1314813 & 169929 & 113262 \\
15 & Jatim & 1.446 .753 & 0 & 1144884 & 1428075 \\
16 & Banten & 225.941 & 1220812 & 75928 & 207263 \\
17 & Bali & 366.657 & 1080096 & 64788 & 347979 \\
18 & Ntb & 182.432 & 1264321 & 119437 & 163754 \\
19 & Ntt & 126.086 & 1320667 & 175783 & 107408 \\
20 & Kalbar & 171.885 & 1274868 & 129984 & 153207 \\
21 & Kalteng & 107.078 & 1339675 & 194791 & 88400 \\
22 & Kalsel & 375.881 & 1070872 & 74012 & 357203 \\
23 & Kaltim & 360.437 & 1086316 & 58568 & 341759 \\
24 & Kalut & 35.113 & 1411640 & 266756 & 16435 \\
25 & Sulut & 187.298 & 1259455 & 114571 & 168620 \\
26 & Sulteng & 91.727 & 1355026 & 210142 & 73049 \\
27 & Sulsel & 358.058 & 1088695 & 56189 & 339380 \\
28 & Sultengg & 67.443 & 1379310 & 234426 & 48765 \\
29 & Gorontalo & 50.551 & 1396202 & 251318 & 31873 \\
30 & Sulbar & 52.416 & 1394337 & 249453 & 33738 \\
31 & Maluku & 37.627 & 1409126 & 264242 & 18949 \\
32 & Malut & 46.586 & 1400167 & 255283 & 27908 \\
33 & Papbar & 18.678 & 1428075 & 283191 & 0 \\
34 & Papua & 44.645 & 1402108 & 257224 & 25967 \\
\hline & & & & & \\
\hline
\end{tabular}

2. Menetapkan nilai k jumlah cluster pelanggan air bersih sebanyak 3 cluster (k-3). Cluster yang dibentuk yaitu claster tertinggi, claster sedang, dan cluster terendah.

3. Menentukan nilai centroid (pusat cluster) awal yang telah ditentukan secara random berdasarkan nilai variabel data yang di cluster sebanyak yang ditentukan 
sebelumnya. Adapun cluster tertinggi diperoleh dari nilai tertinggi pada tabel 3.3, cluster sedang diambil dari nilai rata-rata pada tabel 3, dan cluster terendah diambil dari nilai terkecil pada tabel 3.

Cara mencari nilai centroid data awal untuk iterasi 1 adalah :

$\mathrm{C} 1=139.856 / 775.392 / 237.579 / 67.916 / 200.557 / 394.865 / 60.292 / 76.132 /$

$18.775 / 248.147 / 1.014 .285 / 1.295 .291 / 1.249 .210 / 131.940 / 1.446 .753 /$

$225.941 / 366.657 / 182.432 / 126.086 / 171.885 / 107.078 / 375.881 / 360.437 /$

$35.113 / 187.298 / 91.727 / 358.058 / 67.443 / 50.551 / 52.416 / 37.627 / 46.586 /$

$18.678 / 44.645=$

1.446 .753

Cara yang sama juga di lakukan untuk mencari C2 dan C3 berikut adalah hasil dari data centroid data awal:

Tabel 3. Centroid Data Awal (Iterasi 1)

\begin{tabular}{lc}
\hline C1 & $\mathbf{1 . 4 4 6 . 7 5 3}$ \\
C2 & 301.869 \\
C3 & 18.678 \\
\hline
\end{tabular}

4. Menghitung jarak setiap data pelanggan air bersih terhadap pusat cluster. Setelah data nilai pusat claster awal ditentukan, maka langkah selanjutnya adalah menghitung jarak masing-masing data terhadap pusat cluster dengan menggunakan rumus yang perhitungannya dapat kita lihat sebagai berikut:

Dilakukan perhitungan jarak terhadap data pelanggan air bersih dengan titik pusat (centroid) pada cluster pertama

$\mathrm{D}(1.1)=\sqrt{(1446753-139856)^{2}}=1306897$

$D(1.1)=\sqrt{(1446753-775392)^{2}}=671381$

Sampai dengan D (1.34)

Perhitungan penggunaan air bersih pertama dengan centroid cluster kedua, seperti berikut:

$\mathrm{D}(2.1)=\sqrt{(301869+139856)^{2}}=162013$

$\mathrm{D}(2.2)=\sqrt{\left((301869-775392)^{2}\right.}=743523$

Sampai dengan $\mathrm{D}(2.34)$

Berikut tabel 4 hasil perhitungan jarak data dengan titik pusat pada iterasi 1 menggunakan Elulidean Distance.

Tabel 4. Hasil perhitungan jarak data ke titik pusat pada cluster 1

\begin{tabular}{cccccc}
\hline No & Jarak Terpendek & Hasil & C1 & C2 & C3 \\
\hline 1 & 121178 & C3 & & & 1 \\
2 & 473523 & C2 & & 1 & \\
3 & 64290 & C2 & & 1 & \\
4 & 49238 & C3 & & & 1 \\
5 & 101312 & C2 & & 1 & \\
6 & 92996 & C2 & & 1 & \\
7 & 41614 & C3 & & & 1 \\
8 & 57454 & C3 & & & 1 \\
9 & 97 & C3 & & & 1 \\
10 & 53722 & C2 & & 1 & \\
11 & 432468 & C1 & 1 & & \\
12 & 151462 & C1 & 1 & & \\
13 & 197543 & C1 & 1 & & \\
14 & 113262 & C3 & & & 1 \\
15 & 0 & C1 & 1 & &
\end{tabular}




\begin{tabular}{cccccc}
\hline No & Jarak Terpendek & Hasil & C1 & C2 & C3 \\
\hline 16 & 75928 & C2 & & 1 & \\
17 & 64788 & C2 & & 1 & \\
18 & 119437 & C2 & & 1 & \\
19 & 107408 & C3 & & & 1 \\
20 & 129984 & C2 & & 1 & \\
21 & 88400 & C3 & & & 1 \\
22 & 74012 & C2 & 1 & \\
23 & 58568 & C2 & 1 & \\
24 & 16435 & C3 & & & 1 \\
25 & 114571 & C2 & 1 & \\
26 & 73049 & C3 & & & 1 \\
27 & 56189 & C2 & 1 & \\
28 & 48765 & C3 & & & 1 \\
29 & 31873 & C3 & & & 1 \\
30 & 33738 & C3 & & 1 \\
31 & 18949 & C3 & & 1 \\
32 & 27908 & C3 & & 1 \\
33 & 0 & C3 & & 1 \\
34 & 25967 & C3 & & 1 \\
\hline
\end{tabular}

5. Selanjutnya dilakukan kembali langkah 4 sampai 5. Jika nilai centroid hasil iterasi dengan nilai centroid sebelumnya bernilai sama atau nilai centroid sudah optimal serta posisi cluster data penggunaan air bersih tidak mengalami perubahan lagi maka proses iterasi berhenti. Namun jika nilai centroid tidak sama atau belum optimal serta posisi data rumah tangga kumuh masih berubah maka proses iterasi berlanjut pada iterasi berikutnya.

6. Menghitung titik pusat baru menggunakan hasil dari setiap anggota pada masingmasing cluster

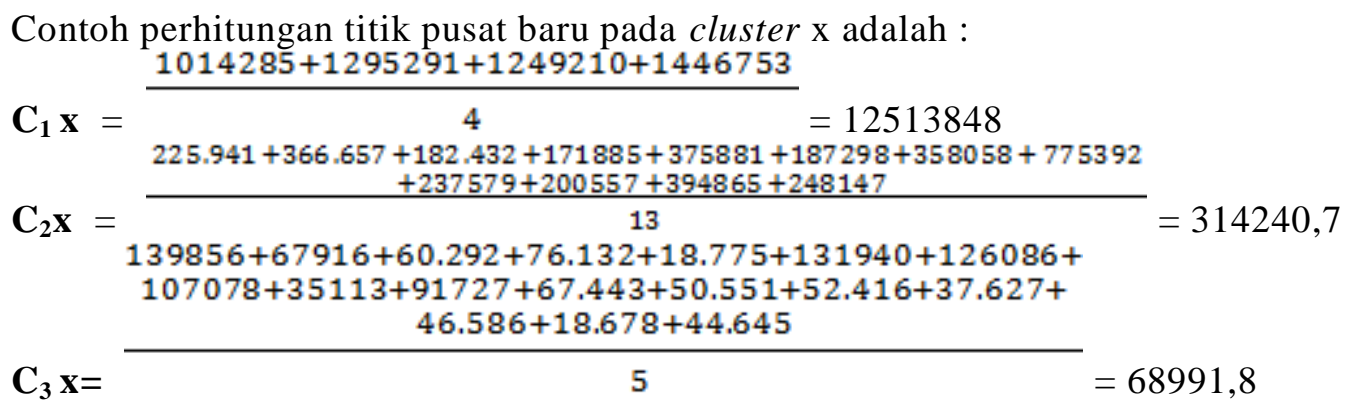

Tabel 5. Hasil perhitungan cluster baru pada iterasi 2

\begin{tabular}{lc}
\hline C1 $=$ Maximum & $\mathbf{1 2 5 1 3 8 4 , 8}$ \\
C2= Average & $\mathbf{3 1 4 2 4 0 , 7}$ \\
C3= Minimum & $\mathbf{6 8 9 9 1 , 8}$ \\
\hline
\end{tabular}

Setelah data nilai pusat cluster iterasi 1 didapat maka langkah selanjutnya adalah melakukan perhitungan jarak terhadap data penggunaan air bersih dengan titik pusat (centroid) pada cluster pertama.

$\mathrm{G}(1.1)=\sqrt{(139856-1251384,8})^{2}=111152875$

$\mathrm{G}(1.2)=\sqrt{(775392-1251384,8})^{2}=47599275$

Dan seterusnya sampai dengan G(1.34)

Perhitungan penggunaan air bersih pertama dengan centroid cluster kedua, seperti berikut:

$\mathrm{G}(2.1)=\sqrt{(139856-314240,7})^{2}=1743846923$

$\mathrm{G}(2.2)=\sqrt{(775392-314240,7})^{2}=4611513077$ 
Dan seterusnya sampai dengan $\mathrm{G}(2.34)$

Berikut tabel 6 hasil perhitungan jarak data dengan titik pusat pada iterasi 2 menggunakan Euclidean Distance.

Tabel 6. Penggunaan Air Bersih Iterasi 2

\begin{tabular}{clrrrccc}
\hline No & Provinsi & C1 & C2 & C3 & Nilai Rata-Rata & C1 & C2 \\
\hline 1 & Aceh & & & 1 & 139856 & 1111528,75 & 174384,6923 \\
2 & Sumut & & 1 & & 775392 & 475992,75 & 461151,3077 \\
3 & Sumbar & & 1 & & 237579 & 1013805,75 & 76661,69231 \\
4 & Riau & & & 1 & 67916 & 1183468,75 & 246324,6923 \\
5 & Jambi & & 1 & & 200557 & 1050827,75 & 113683,6923 \\
6 & Sumsel & & 1 & & 394865 & 856519,75 & 80624,30769 \\
7 & Bengkulu & & & 1 & 60292 & 1191092,75 & 253948,6923 \\
8 & Lampung & & & 1 & 76132 & 1175252,75 & 238108,6923 \\
9 & Kep.Babel & & & 1 & 18775 & 1232609,75 & 295465,6923 \\
10 & Kep. Riau & & 1 & & 248147 & 1003237,75 & 66093,69231 \\
11 & Dki & 1 & & & 1014285 & 237099,75 & 700044,3077 \\
$\ldots$ & $\ldots$ & $\ldots$ & $\ldots$ & $\ldots$ & $\ldots$ & $\ldots$ & $\ldots$ \\
$\ldots$ & $\ldots$ & $\ldots$ & $\ldots$ & $\ldots$ & $\ldots$ & $\ldots$ & $\ldots$ \\
32 & Malut & & & 1 & 46586 & 1204798,75 & 267654,6923 \\
33 & Papbar & & & 1 & 18678 & 1232706,75 & 295562,6923 \\
34 & Papua & & & 1 & 44645 & 1206739,75 & 269595,6923 \\
\hline
\end{tabular}

Data yang memiliki jarak terkecil dengan centroid akan menjadi anggota pada kelompok tersebut. Proses perhitungan dilakukan hingga iterasi yang diperoleh memiliki hasil yang sama dengan iterasi sebelumnya. Pada penelitian ini proses berhenti hingga iterasi 5

Tabel 7. Pengguna Air Bersih Iterasi 5

\begin{tabular}{|c|c|c|c|c|c|c|c|}
\hline No & Provinsi & C1 & $\mathrm{C2}$ & $\mathrm{C3}$ & Nilai Rata-Rata & $\mathrm{C1}$ & $\mathrm{C2}$ \\
\hline 1 & Aceh & & & 1 & 139.856 & 1111528,75 & 231583,6667 \\
\hline 2 & Sumut & & 1 & & 775.392 & 475992,75 & 403952,3333 \\
\hline 3 & Sumbar & & 1 & & 237.579 & 1013805,75 & 133860,6667 \\
\hline 4 & Riau & & & 1 & 67.916 & 1183468,75 & 303523,6667 \\
\hline 5 & Jambi & & & 1 & 200.557 & 1050827,75 & 170882,6667 \\
\hline 6 & Sumsel & & 1 & & 394.865 & 856519,75 & 23425,33333 \\
\hline 7 & Bengkulu & & & 1 & 60.292 & 1191092,75 & 311147,6667 \\
\hline 8 & Lampung & & & 1 & 76.132 & 1175252,75 & 295307,6667 \\
\hline 9 & Kep.Babel & & & 1 & 18.775 & 1232609,75 & 352664,6667 \\
\hline 10 & Kep. Riau & & 1 & & 248.147 & 1003237,75 & 123292,6667 \\
\hline 11 & Dki & 1 & & & 1.014 .285 & 237099,75 & 642845,3333 \\
\hline 12 & Jabar & 1 & & & 1.295 .291 & 43906,25 & 923851,3333 \\
\hline 13 & Jateng & 1 & & & 1.249 .210 & 2174,75 & 877770,3333 \\
\hline 14 & Diy & & & 1 & 131.940 & 1119444,75 & 239499,6667 \\
\hline 15 & Jatim & 1 & & & 1.446 .753 & 195368,25 & 1075313,333 \\
\hline 16 & Banten & & & 1 & 225.941 & 1025443,75 & 145498,6667 \\
\hline 17 & Bali & & 1 & & 366.657 & 884727,75 & 4782,666667 \\
\hline 18 & Ntb & & & 1 & 182.432 & 1068952,75 & 189007,6667 \\
\hline 19 & $\mathrm{Ntt}$ & & & 1 & 126.086 & 1125298,75 & 245353,6667 \\
\hline 20 & Kalbar & & & 1 & 171.885 & 1079499,75 & 199554,6667 \\
\hline 21 & Kalteng & & & 1 & 107.078 & 1144306,75 & 264361,6667 \\
\hline 22 & Kalsel & & 1 & & 375.881 & 875503,75 & 4441,333333 \\
\hline 23 & Kaltim & & 1 & & 360.437 & 890947,75 & 11002,66667 \\
\hline 24 & Kalut & & & 1 & 35.113 & 1216271,75 & 336326,6667 \\
\hline 25 & Sulut & & & 1 & 187.298 & 1064086,75 & 184141,6667 \\
\hline 26 & Sulteng & & & 1 & 91.727 & 1159657,75 & 279712,6667 \\
\hline 27 & Sulsel & & 1 & & 358.058 & 893326,75 & 13381,66667 \\
\hline 28 & Sultengg & & & 1 & 67.443 & 1183941,75 & 303996,6667 \\
\hline 29 & Gorontalo & & & 1 & 50.551 & 1200833,75 & 320888,6667 \\
\hline 30 & Sulbar & & & 1 & 52.416 & 1198968,75 & 319023,6667 \\
\hline 31 & Maluku & & & 1 & 37.627 & 1213757,75 & 333812,6667 \\
\hline 32 & Malut & & & 1 & 46.586 & 1204798,75 & 324853,6667 \\
\hline 33 & Papbar & & & 1 & 18.678 & 1232706,75 & 352761,6667 \\
\hline 34 & Papua & & & 1 & 44.645 & 1206739,75 & 326794,6667 \\
\hline
\end{tabular}


Perhitungan manual pada data penggunaan air bersih diatas didapatkan hasil akhir yang dimana pada iterasi 5 pengelompokan data yang dilakukan terhadap 3 cluster dengan iterasi 4 didapatkan hasil yang sama. Hasil dari kedua iterasi tersebut benilai $\mathrm{C} 1=4, \mathrm{C} 2=8$, dan $\mathrm{C} 3=22$ pada posisi data tiap cluster $\mathrm{x}$. Sehingga posisi cluster pada data tersebut tidak mengalami perubahan lagi maka proses iterasi berhenti. Berdasarkan posisi cluster masing-masing data penggunaan air bersih dan nilai cluster hasil iterasi kelima maka dapat disimpulkan sebagai berikut:

1. Cluster Tertinggi dengan jumlah data penggunaan air bersih sebanyak 4 provinsi yaitu, DKI Jakarta, Jawa Barat, Jawa Tengah, Jawa Timur

2. Cluster Sedang dengan jumlah data penggunaan air bersih sebanyak 8 Provinsi yaitu, Sumatera Utara, Sumatera Barat, Sumatera Selatan, Kep. Riau, Bali, Kalimantan Selatan, Kalimantan Timur, Sulawesi Selatan

3. Cluster Terendah dengan jumlah sebanyak 22 Provinsi yaitu, Aceh, Riau, Jambi, Bengkulu, Lampung, Bangka Belitung, Yogyakarta, Banten, Nusa Tenggara Barat, Nusa Tenggara Timur, Kalimantan Barat, Kalimantan Tengah, Kalimantan Utara, Sulawesi Selatan, Sulawesi Tengah, Sulawesi Tenggara, Grontalo, Sulawesi Barat, Maluku, Maluku Utara, Papua Barat, Papua.

\section{Kesimpulan}

Berdasarkan pembahasan sebelumnya dapat disimpulkan bahwa:

a) Hasil penelitian yang diperoleh dapat disimpulkan bahwa perhitungan manual excel yang di kombinasikan dengan rapidminer, bahwa metode tersebut mampu untuk menyelesaikan sebuah pengelompokan berdasarkan provinsi.

b) Hasil yang diperoleh dari metode k-means clustering yang di implementasikan ke dalam rapidminer memiliki nilai validasi yang sama yaitu menghasilkan beberapa cluster yaitu cluster tinggi , 4, cluster rendah 6 dan tinggi 24 yang masing-masing cluster memiliki hasil yang berbeda.

\section{Daftar Pustaka}

[1] P. Soepomo, "2613-7473-1-Pb," Vol. 2, 2014.

[2] T. Imandasari, E. Irawan, A. P. Windarto, Dan A. Wanto, "Algoritma Naive Bayes Dalam Klasifikasi Lokasi Pembangunan Sumber Air," Pros. Semin. Nas. Ris. Inf. Sci., No. November, 2019.

[3] A. P. Windarto, "Implementation Of Data Mining On Rice Imports By Major Country Of Origin Using Algorithm Using K-Means Clustering Method," Int. J. Artif. Intell. Res., Vol. 1, No. 2, Hal. 26-33, 2017.

[4] F. Nasari Dan C. J. M. Sianturi, "Penerapan Algoritma K-Means Clustering Untuk Pengelompokkan Penyebaran Diare Di Kabupaten Langkat," Cogito Smart J., Vol. 2, No. 2, Hal. 108-119, 2016.

[5] W. Wardhani, Anindya Khrisna, "Implementasi Algoritma K-Means Untuk Pengelompokkan Penyakit Pasien Pada Puskesmas Kajen Pekalongan," J. Transform., Vol. 14, No. 1, Hal. 30-37, 2016.

[6] M. G. Sadewo, A. P. Windarto, Dan D. Hartama, "Penerapan Datamining Pada Populasi Daging Ayam Ras Pedaging Di Indonesia Berdasarkan Provinsi Menggunakan K-Means Clustering," Infotekjar (Jurnal Nas. Inform. Dan Teknol. Jaringan), Vol. 2, No. 1, Hal. 60-67, 2017.

[7] I. Parlina, A. P. Windarto, A. Wanto, Dan M. R. Lubis, "Memanfaatkan Algoritma K-Means Dalam Menentukan Pegawai Yang Layak Mengikuti Asessment Center Untuk Clustering Program Sdp," Cess (Journal Comput. Eng. Syst. Sci., Vol. 3, No. 1, Hal. 87-93, 2018. 